\title{
СОПОСТАВЛЕНИЕ ПОДНЯТИЯ ЗЕМНОЙ ПОВЕРХНОСТИ ПРИБРЕЖНЫХ И ВНУТРЕННИХ ЧАСТЕЙ СЕВЕРО-ЗАПАДА КОЛЬСКОГО РЕГИОНА
}

Толстобров Д.С., Толстоброва А.Н., Колька В.В., Корсакова О.П.

Геологический институт КНЦ РАН, Anamumbl, tolstobrov@geoksc.apatity.ru

\section{Введение}

C конца XX в. в пределах Фенноскандии для изучения вертикальных движений земной поверхности и связанного с ними перемещения береговой линии моря применяется метод изолированных бассейнов [8]. С использованием данной методики на баренцевоморском побережье Кольского региона были проведены работы в районах пос. Дальние Зеленцы [10], г. Никель [6] и г. Полярный [7]. Для каждого района был установлен характер поднятия земной поверхности и построен график перемещения береговой линии в поздне- и послеледниковое время (рис. 1). В последнее время аналогичные работы были проведены во внутренних частях Кольского региона. Были исследованы донные отложения из котловин озер, расположенных в районах долин рек Тулома $[3,4]$ и Лотта [5]. Полученные данные существенно дополнили уже имеющиеся сведения по перемещению береговой линии моря и позволили оценить темпы и градиент поднятия земной поверхности во внутренних частях Кольского региона. В данной работе приводятся результаты изучения вертикальных движений северо-запада Кольского региона в голоцене, и сопоставление амплитуды и скорости поднятия прибрежных и внутренних районов.

\section{Сопоставление амплитуды и скорости поднятия земной поверхности}

Для сопоставления амплитуды и скорости поднятия земной поверхности северо-западной части Кольского региона на один график были помещены кривые относительного перемещения береговой линии, построенные и для прибрежных частей района исследования, и для внутренних (рис. 1).
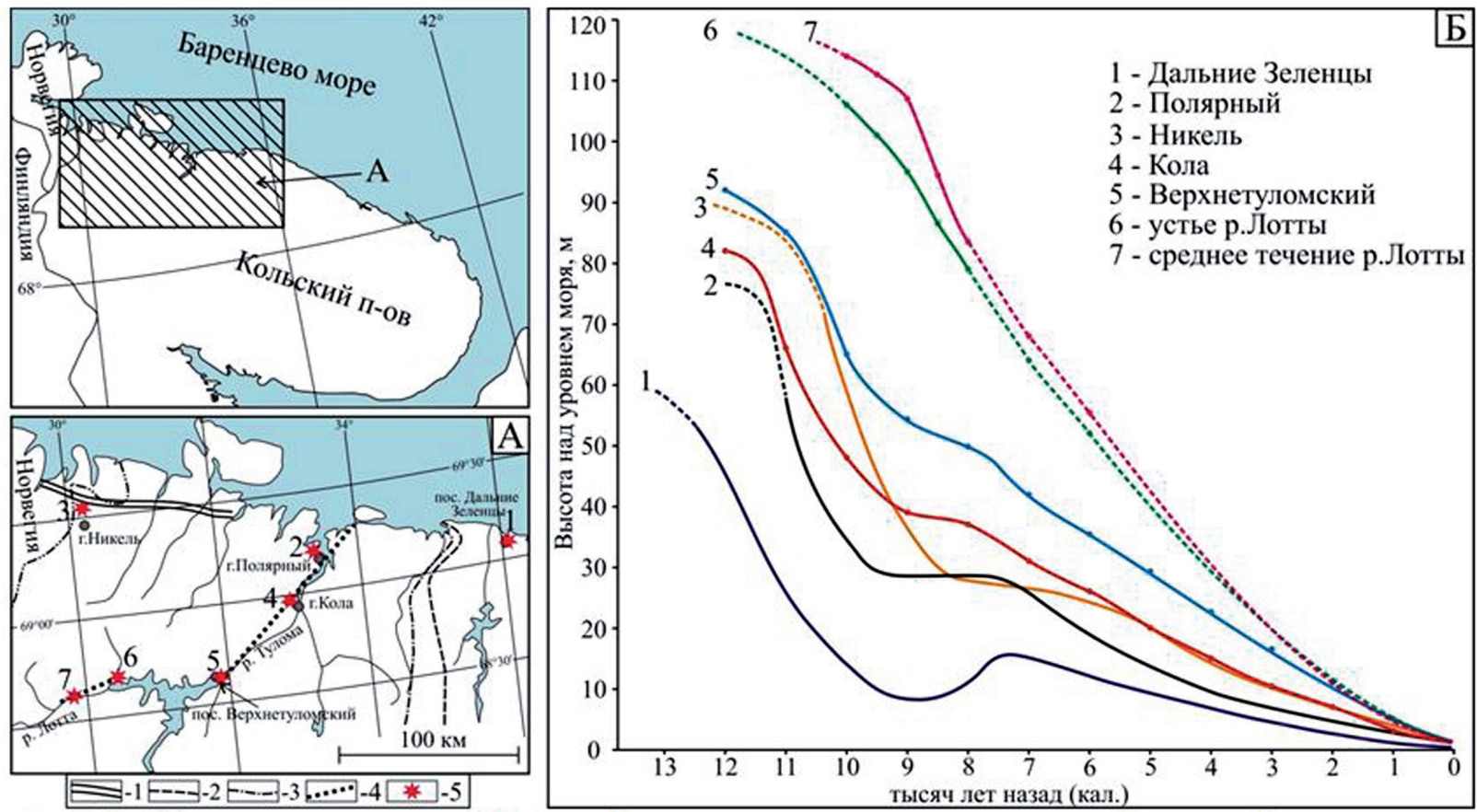

Рис. 1. Районы исследования (А) и графики относительного изменения береговой линии Баренцева моря (Б) на северо-западе Кольского региона.

1-3 - положение краевых ледниковых образований по [9]: 1 - Сальпаусселька I (13100-12700 л.н. (кал.)), 2 - Сальпаусселька II (13000-11500 л.н. (кал.)), 3 - Тромсе-Люнген (12900-11500 л.н. (кал.)); 4 - линии профилей диаграмм для районов долин р. Тулома [4] и р. Лотта [5]; 5 - районы исследования, для которых приведены графики относительного изменения береговой линии. 


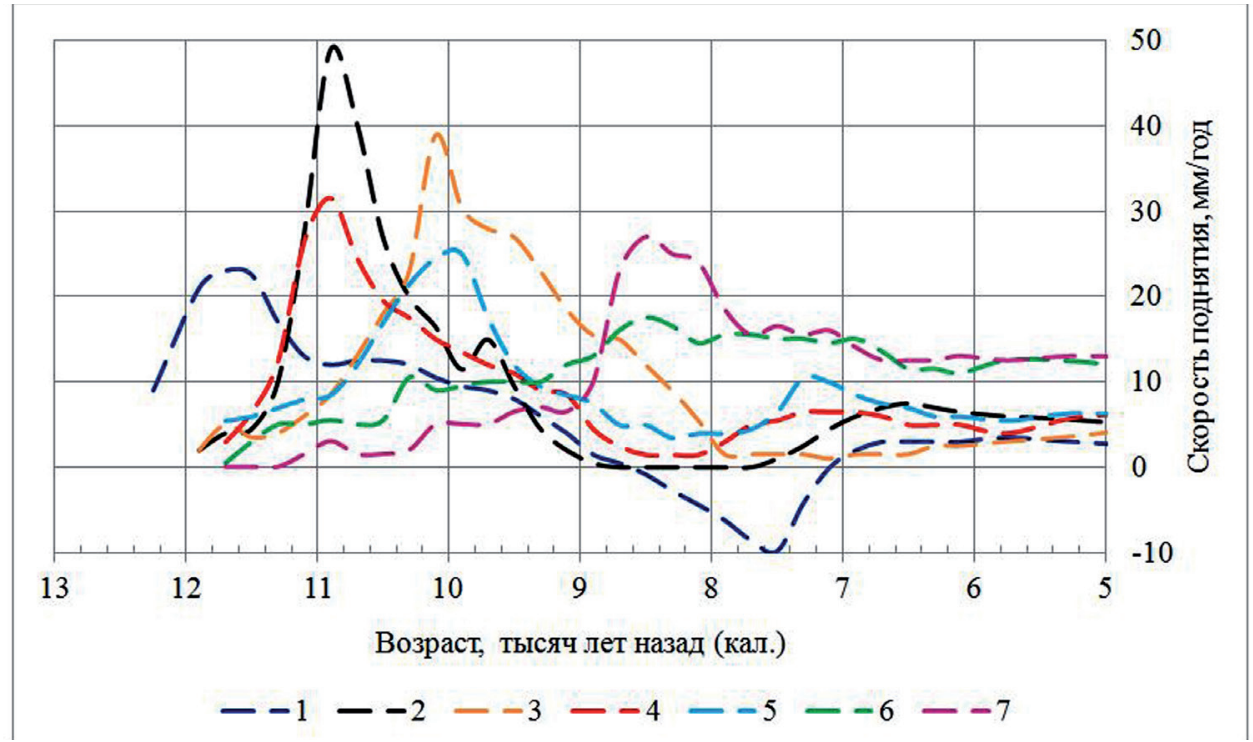

Рис. 2. Графики скоростей поднятия земной поверхности в различных частях северо-запада Кольского региона. 1 - Дальние Зеленцы; 2 - Полярный; 3 - Никель; 4 - Кола; 5 - Верхнетуломский; 6 - устье р. Лотты; 7 - среднее течение р. Лотты.

Для прибрежных частей были использованы графики из ранее опубликованных работ $[6,7,10]$. Для внутренних частей Кольского региона были построены аналогичные графики перемещения береговой линии моря на основании диаграмм относительного поднятия земной поверхности в районах долины р. Тулома и Кольском заливе [4] и долины р. Лотта [5]. Для этого в выбранных местах на диаграмме относительного поднятия проводится вертикальная линия, места пересечения данной линии с линиями относительного поднятия земной поверхности отражают положение морской границы в данном районе. Таким образом, мы располагаем информацией о пространственном и временном положении морской границы. Такие графики были построены для районов г. Колы и пос. Верхнетуломского в Туломской депрессии, а также для района устья р. Лотты и среднего течения р. Лотты в районе р. Няаннамйоки (рис. 1).

На основании этих кривых перемещения береговой линии бассейнов в различных частях северо-запада Кольского региона далее были рассчитаны скорости поднятия земной поверхности (рис. 2).

Из графиков на рисунке 1 Б видно, что амплитуда поднятия земной поверхности увеличивается и в направлении с востока на запад (в районе пос. Дальние Зеленцы амплитуда составила 60 м, в районе г. Никель- 90 м), и в направлении от побережья к внутренним частям континента (в районе г. Полярный - около 80 м, в районе р. Лотта - около 120 м). При этом практически все графики перемещения береговой линии (кроме графиков для Лоттинской депрессии) имеют одинаковый характер изменения во времени (рис. 1). На начальном этапе развития после освобождения от ледникового покрова во всех районах отмечается резкое понижение береговой линии моря, что указывает на интенсивное поднятие земной поверхность в этот период. Аналогичный характер поднятия в начальные этапы после деградации ледникового покрова наблюдается практически во всех исследованных областях Фенноскандии [1, 2, 11 и др.].

В интервале времени 12500-11500 калиброванных лет назад (л.н. (кал.)) большая часть территории северо-запада Кольского региона была ещё покрыта ледником. В восточной части района исследования (пос. Дальние Зеленцы), где ледниковый покров уже отступил, происходило поднятие земной поверхности с постепенным увеличением скорости (рис. 2). Максимальная скорость поднятия в данном районе фиксируется в интервале времени примерно 11900-11500 л.н. (кал.), ее значение достигало 20-25 мм/год.

В интервале времени 11500-9500 л.н. (кал.) значительная часть района исследования освободилась ото льда, но юго-западные его области (Лоттинская депрессия) ещё были заблокированы 
ледниковым покровом. На северо-востоке от района исследования (район пос. Дальние Зеленцы) скорость поднятия постепенно уменьшается (рис. 2), в то время как в пределах западной части баренцевоморского побережья Кольского региона (районы г Никель и г. Полярный) и в пределах Туломской депрессии в это время отмечается максимальная скорость поднятия (рис. 2). На побережье скорость поднятия достигает значения 50 мм/год, а в долине р. Туломы около 30 мм/год.

В интервале времени 9500-7500 л.н. (кал.) из-за трансгрессии Тапес на побережье расчетная скорость поднятия уменьшается практически до 0 мм/год, а в некоторых его районах наблюдается относительное погружение земной поверхности (район Дальних Зеленцов) (рис. 1 и 2). В пределах Туломской депрессии в данном интервале времени также отмечается относительное уменьшение скорости поднятия до 5 мм/год. В Лоттинской депрессии, несмотря на трансгрессию Тапес в пределах Баренцева моря, отмечается максимальная скорость поднятия до 27 мм/год.

\section{Заключение}

В позднеледниковье и голоцене на северо-западе Кольского региона амплитуда и скорость поднятия земной поверхности возрастает в направлении с северо-востока на юго-запад. В начале голоцена наибольшая скорость поднятия отмечается в прибрежных частях района исследования. Со временем скорость поднятия материковой части начинает преобладать над прибрежной. Такой характер поднятия, видимо, связан с более ранним освобождением прибрежной части от ледникового покрова. Таким образом, максимальная скорость (интенсивность) поднятия отмечается на начальных этапах после дегляциации территории. В областях, раньше всего освободившихся ото льда (район пос. Дальние Зеленцы), максимальная скорость поднятия, приблизительно 25 мм/год, соответствует временному интервалу 12000-11500 лет назад. В районе Лоттинской депрессии, освободившейся ото льда позже, максимальная скорость поднятия, около 27 мм/год, фиксируется в интервале времени 9000-8000 лет назад.

Работа выполнена при частичной поддержке грантов РФФИ № 16-05-00311-А и №17-30550019-мол_нр и темы НИР ГИ КНЦ РАН № 0231-2015-0010.

\section{Литература}

1. Колька В.В., Корсакова О.П., Шелехова Т.С., Алексеева А.Н., Толстобров Д.С., Лаврова Н.Б. Хронология и причины перемещения береговой линии Белого моря в голоцене по данным изучения донных отложений озер из района Кузема (северная Карелия). Известия русского географического общества. 2014. Вып. 6. С. 14-26.

2. Колька В.В., Корсакова О.П., Шелехова Т.С., Толстоброва А.Н. Восстановление относительного положения уровня Белого моря в позднеледниковье и голоцене по данным литологического, диатомового анализов и радиоуглеродного датирования донных отложений малых озер в районе пос. Чупа (северная Карелия). Вестник МГТУ. Мурманск: МГТУ. 2015. Т. 18. №2. С. 255-268.

3. Толстобров Д.С., Толстоброва А.Н., Колька В.В., Корсакова О.П. Постледниковое поднятие земной коры в северо-западной части Кольского региона // Вестник МГТУ. Мурманск: МГТУ. 2015. Т. 18. №2. C. 295-306.

4. Толстобров Д.С., Колька В.В., Толстоброва А.Н., Корсакова О.П. Опыт хронологической корреляции береговых форм рельефа голоценового моря в депрессии реки Тулома и Кольском заливе // Вестник МГТУ. Мурманск: МГТУ. 2016. Т. 19. №1/1. С.142-150.

5. Толстобров Д.С., Толстоброва А.Н. Неотектонические движения на северо-западе Кольского региона (долина р. Лотта) // Матер. XXVI молодежной научной школы-конференции, посвященной памяти члена-корреспондента АН СССР К.О. Кратца и академика РАН Ф.П. Митрофанова. Петрозаводск: КарНЦ РАН. 2015. С. 146-148

6. Corner G.D., Kolka V.V., Yevzerov V.Ya., Moller J.J. Postglacial relative sea-level change and stratigraphy of raised coastal basins on Kola Peninsula, northwest Russia. Global and Planetary Change. 2001. V. 31. P. $153-175$.

7. Corner G.D., Yevzerov V.Ya., Kolka V.V., Moller J.J. Isolation basin stratigraphy and Holocene relative sea-level change at the Norwegian-Russian border north of Nikel, northwest Russia. Boreas. 1999. V. 28. N 1. P. 146-166.

8. Donner J., Eronen M., Jungner H. The dating of the Holocene relative sea-level changes in Finnmark, North Norway // Norsk geografisk Tidsskrift. 1977. V. 31. P. 103-128.

9. Ekman I., Iljin V. Deglaciation, the Younger Dryas end moraines and their correlation in the Karelian ASSR and adjacent areas. - Eastern Fennoscandian Younger Dryas end moraines. Espoo, Geol. Survey Finland. 1991. P. 73-99.

10. Snyder J.A., Korsun S.A., Forman S.L. Postglacial emergence and the Tapes transgression, north-central Kola Peninsula, Russia. Boreas. 1996. V. 25. P. 47-56.

11. Svendsen J.I., Mangerud J. Late Weichselian and Holocene sea-level history for a cross-section of western Norway // Journal of Quaternary Science. 1987. V. 2. №2. P. 113-132. 